\title{
NATURAL VALUES OF THE URBAN RIVER VALLEY AND THE POSSIBILITIES OF ITS DEVELOPMENT - BYSTRZYCA RIVER VALLEY STUDY CASE (POLAND)
}

\author{
Joanna SENDER * and Weronika MASLANKO ** \\ * University of Life Sciences in Lublin, Department of Landscape Ecology and Nature Conservation, \\ Dobrzańskiego Street 37, Lublin, Poland, PL-20-262, joanna.sender@up.lublin.pl \\ ** University of Life Sciences in Lublin, Department of Landscape Ecology and Nature Conservation, \\ Dobrzańskiego Street 37, Lublin, Poland, PL-20-262, weronika.maslanko@up.lublin.pl
}

DOI: $10.2478 /$ trser-2018-0015

KEYWORDS: river valley, public participation, SWOT analysis, concept of development, the Bystrzyca River.

\section{ABSTRACT}

The paper presents the multi-functionality of the river valley in ecological, social and economic terms. The biotic and abiotic elements, as well as aspects of its protection and environmental threats were characterized. Successively, based on above research, public participation and SWOT analysis, a variant design was carried out. Finally, the concept of the development of the Bystrzyca River valley and its surroundings was developed, mainly aimed at the protection, enrichment, development of recreation and fulfill social needs in accordance with principles of landscape design and sustainable development.

ZUSAMMENFASSUNG: Die natürlichen Werte eines Flusstales im Stadtgebiet und die Möglichkeiten seiner Entwicklung - Fallstudie Bystrzyca-Fluss (Polen).

Vorliegende Arbeit stellt die vielfache Funktion eines Flusstales in ökologischer, sozialer und wirtschaftlicher Hinsicht vor. Die biotischen und abiotischen Elemente, aber auch Aspekte ihres Schutzes und der Umweltgefährdungen werden charakterisiert. In der Folge wurde auf Grundlage der durchgeführten Untersuchungen, der öffentlichen Beteiligung und der SWOT-Analyse eine Design Variante ausgearbeitet. Schließlich wurde ein Entwicklungskonzept des Bystrzyca Flusstales und seiner Umgebung erstellt, vor allem in bezug auf Schutz, Förderung der Vielfalt, Entwicklung der Erholungsangebote und die Erfüllung der sozialen Erfordernisse im Einklang mit den Prinzipien der Landschaftsgestaltung und der nachhaltigen Entwicklung.

REZUMAT: Valori naturale în valea unui râu în intravilan și posibilităţile de dezvoltare - studiu de caz valea râului Bystrzyca (Polonia).

Lucrarea de față prezintă multifuncționalitatea văii unui râu din punct de vedere ecologic, social și economic. Elementele biotice și abiotice, dar și aspecte de protecție și ale amenințării mediului sunt descrise și caracterizate. În baza cercetărilor efectuate, a participării publicului și a analizei SWOT a fost elaborată o variantă de design. In final a fost realizat un concept de dezvoltare a văii Bystrzyca și a împrejurimilor sale în special cu referiri asupra ocrotirii, a îmbogăţirii diversității, a dezvoltării ofertelor de recreere și a îndeplinirii cerințelor sociale în acord cu principiile de planificare a peisajului și dezvoltării durabile. 


\section{INTRODUCTION}

From ages, human activity related to satisfying its social, economic and cultural needs caused changes of aquatic environment. These changes have a varying degree and intensity, depending on the particular component of environment, a geographic location, a technological progress, or ecological awareness of society. Over time, social goals have changed and thus the way of using and treating environmental components, including river valleys. (Kijowski and Rączkowski, 2007)

Hydrotechnical works in river valleys started in Europe at the end of the 18th and 19th centuries. The reason was floods that negatively impacted agricultural economy, leading to disasters and to crop failures in some regions. The construction of the flood embankments began; the trough was made to allow and accelerate the flow of waves and ice. For the same purpose, tree and shrub vegetation was removed from floodplains. (Plit, 2008)

Due to the demographic growth in Poland, the demand for arable land increased, resulting in the melioration and drainage of damp habitats for the agricultural development of the valley floor. Water transport was widespread among cities, so the troughs were straightened, obstacles for ships in the form of natural islands, tips or shoals were liquidated. Rivers were also oriented into one trough, which was then narrowed with spurs. The construction of canals between river basins has begun. (Plit, 2008)

As a result of climate change, in the XIX century problems with periodic water shortages in the river beds have begun to emerge. This has led a need to build retention tanks in order to prevent floods and water shortages, as well as to stabilize river flows. Ameliorative works were still being massively carried out, which did not include only the valleys of the largest Polish rivers, but also valleys and glacial valleys of small streams, swamps, bogs and even large fragments of forests growing in wetlands (Plit, 2008).

The turn of the 19th and 20th centuries marked a significant reverse from farming for buildings development. Despite planning indications of local management, landscape protection and flood risk, the number of buildings in the immediate vicinity of rivers has still increased. It was influenced by the population' desire to settle in nice, aesthetic and naturally valuable places. In spite of the low water availability of Poland, the reduction and regulation of rivers is still planned (Plit, 2008).

A large part of waters, characterized by favorable location and suitable conditions was built-up with recreational facilities for the tourism development (Bernat, 2010).

Hydrotechnical investments conducted throughout Poland, have led to change a landscape model of river valleys in the direction of their considerable impoverishment, simplification of the structure and replacement by monocultures (Żelazo, 2006). Intensification of hydrotechnical works has led to far-reaching changes in the environment. The first of them was drying of marshes, meadows and small water bodies - ecosystems with a great ecological importance, as within poor water regions they constitute so-called "stepping stones" (MacArthur and Wilson, 1967; Diamond et al., 1976) for a variety of animal and plant species, especially in terms of fragmentation (Fahrig, 2003; Wilcove et al., 1998) and habitat lost (Sala et al., 2000; Benton et al., 2003; Kerr and Deguise 2004; Crooks et al., 2004; Luck et al., 2004). In addition, they increase resources of small retention of surface water, contributing to mitigate effects of floods, and their impact on the microclimate minimizes extreme events such as droughts (Bullock and Acreman, 2003; Erwin, 2009; Lipka and Stabryła, 2012). As a result of widespread melioration and intake of surface waters, a significant salinisation of groundwater was made as a consequence of their level decrease. The low level of water in soil 
causes decreasing of its filtering capacity, worsening physicochemical properties of soils, sometimes leading to their complete degradation through processes of peat decomposition. The number of bushes and trees in floodplains has also been reduced, depriving a river valley of a buffer zone protecting from flow of pollution from agricultural fields, road and rail infrastructure, as well as from developed areas producing large quantity of solid waste, industrial and municipal waste water (Izydorczyk et al., 2010). A large number of rivers have become a carrier of biogenes and pollutants, by which some of native plant and animal species died away, whereas water reservoirs were increasingly subjected to eutrophication (Plit, 2008). As a result of the destruction of aquatic vegetation such as macrophytes, rushes, alders, swamps or peat bogs, cosmopolitan vegetation have been replaced instead of rare native species. This phenomenon is the most intense in urban and suburban areas, where plant habitats have been consolidated for the benefit of ruderal vegetation (Matuszkiewicz, 1999).

In the context of the Water Framework Directive of the European Parliament and the Council constituted on 23rd October 2000, the significant aim of water management is to limit the decreasing of water quality and to reach its good quality. According to the WFD a good ecological status is firstly induced by biological, hydromorphological, and physicochemical elements.

The goal of this research was to evaluate the ecological status of a sector of the Bystrzyca River and to design concept' variants of its development, based on principles of landscape design, nature conservation and social needs.

\section{MATERIAL AND METHODS}

The Bystrzyca River has the highest importance for the Lublin city being its morphological axis. It crosses Lublin from the south to the north-west, making it one of the most important ecological corridors. The total length of the river is $70.3 \mathrm{~km}$, among about 22 $\mathrm{km}$ flows within the city. The width of its valley ranges between 1,000-1,500 $\mathrm{m}$. On the Bystrzyca River, in the southern part of the city, a retention reservoir called the Zemborzyce Reservoir was built.

The study included a part of the Bystrzyca River within the boundaries of the Lublin municipality that stretches from $14.9 \mathrm{~km}$ to $22 \mathrm{~km}$ (Fig. 1). The length of the river in research area was $7.064 \mathrm{~km}$. Areas along the analyzed section were characterized by lack of tourist development such as walking or bicycle paths, making it inaccessible to users. The analysis also included areas adjacent to the river bed of a total area of $120,000 \mathrm{~m}^{2}$.

The analysis of landscape structure and land cover was based on field observations and interpretation of cartographic studies. Maps of land cover and terrain were developed. On the basis of simultaneously imposition of the borders of boundaries of land cover and terrain, the area was divided into natural-landscape units system (JPK) (Chmielewski, 2012).

In order to determine the social expectations of the research area, a questionnaire was carried out. It was available on the most frequently visited by residents of Lublin websites. The questionnaire consisted of three personal questions and six questions directly related to the expectations of the society regarding to the analyzed river section. Respondents were divided into five age groups: under 18, 18-25, 25-35, 35-50 and over 50. First, respondents were asked about forms of active tourism most often cultivated by them. Further questions were related directly to the Bystrzyca River valley and its infrastructure, as well as respondents' choice of desirable changes that would improve attractiveness of the river valley (choice of maximum two options). At the end respondents were to evaluate an attractiveness of tourist infrastructure in the Bystrzyca River valley on a scale from one (very bad) to five (very good). 


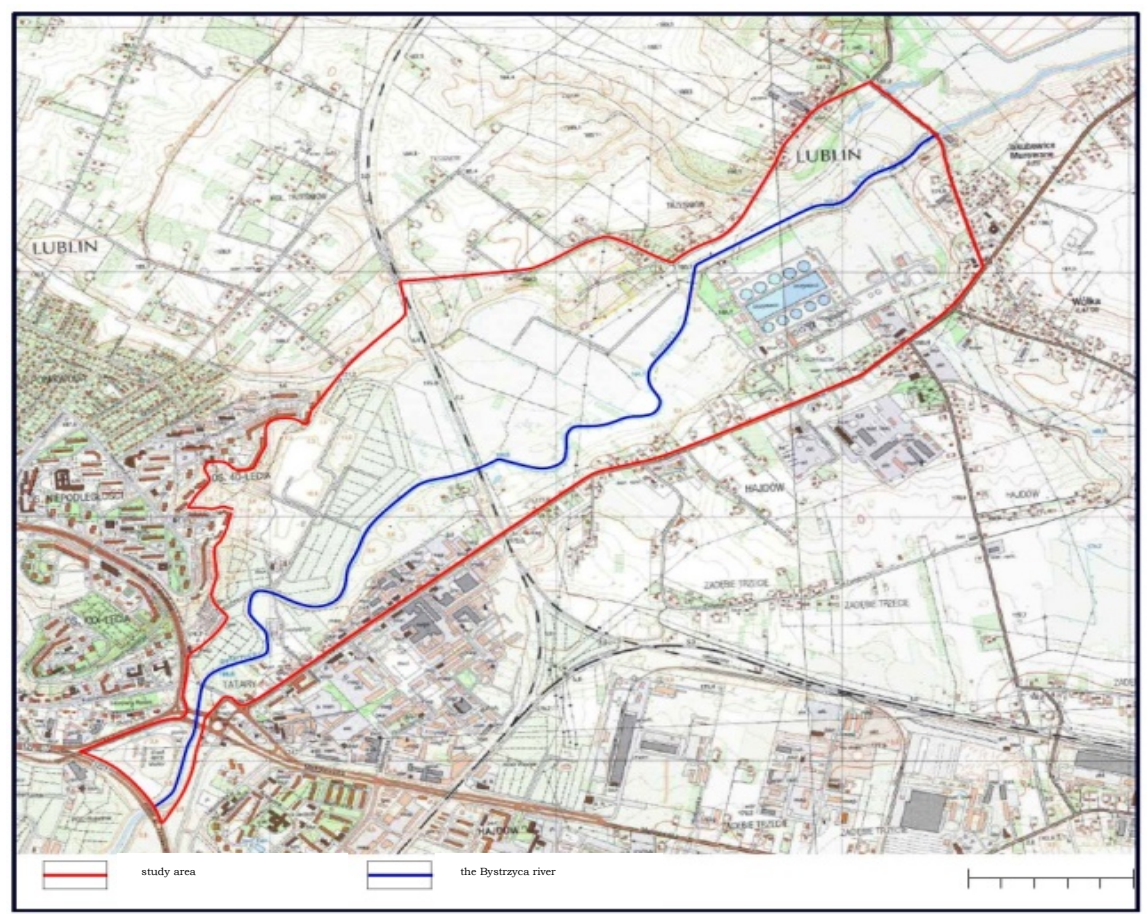

Figure 1A: Study area. B. Visual characteristics of individual fragments.

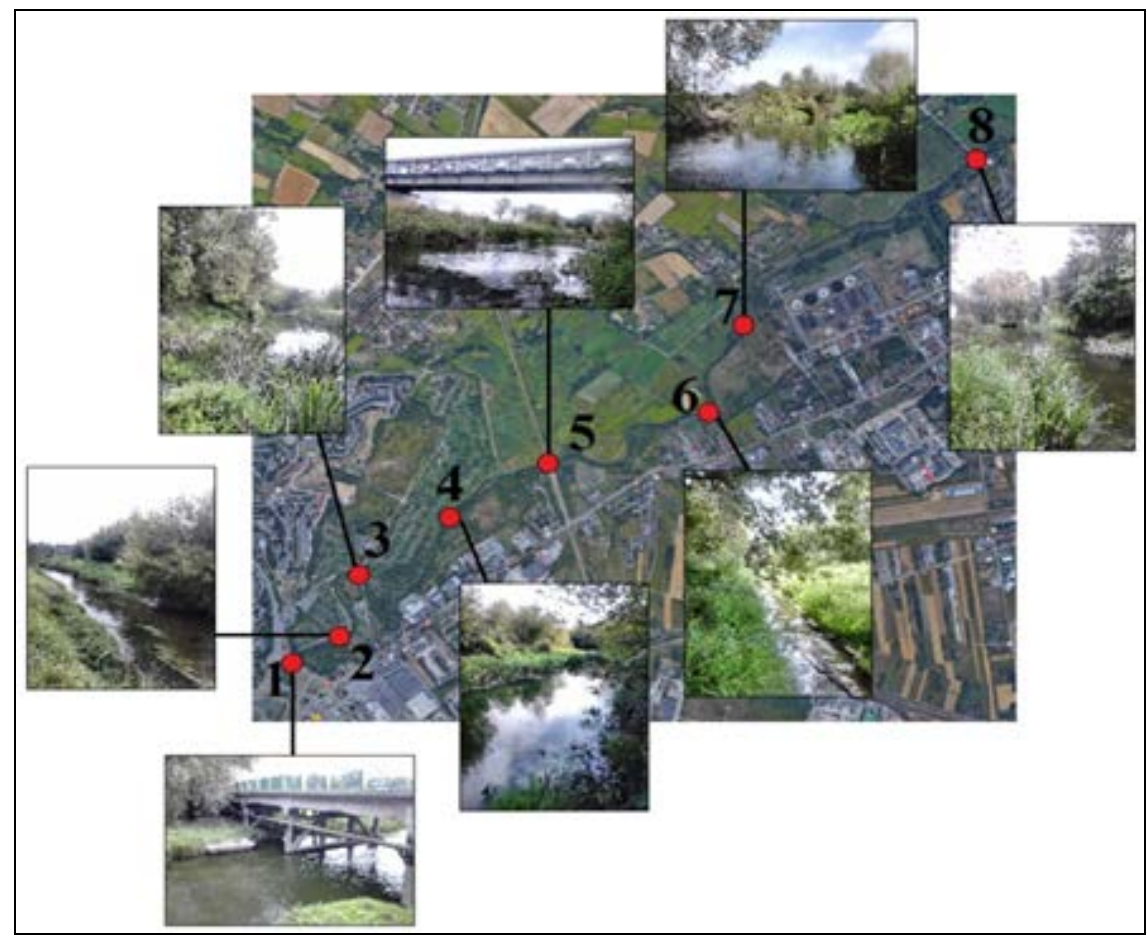

Figure 1B: Visual characteristics of individual fragments. 
In order to identify strengths and weaknesses, as well as the threats and opportunities of the analyzed fragment of the Bystrzyca River, a SWOT analysis (strengths, weaknesses, opportunities and threats) was also conducted. In the first stage of the analysis, a status of the landscape was diagnosed. It was based on the assessment of such domains as: a natural heritage (assessment of natural values); a cultural heritage (assessment of cultural values); a society (assessment of the degree of integration of the local community and objects conducive to this process); a spatial planning (assessment of the order of construction and communication infrastructure); an economy (assessment of the impact of the economy on the values of the examined area) and a landscape physiognomy (assessment of forms of terrain and land cover).

Based on the point scale, each of the domains was evaluated by:

a. strengths, like resources and facilities that can allow for the development of the research area, where: zero points - lack, one point - weak, two - small, three - moderate, four - strong, five - very strong.

b. opportunities like positive phenomena and trends which, if properly used, will support development or weaken threats, the score as above.

c. weaknesses, like factors limiting the area development, the score as above, threats, like phenomena and tendencies perceived as negative, which influence the limitation of the area development, the score as above.

After completing the balance of points, the above analysis was the starting point for the variant design. It consisted in setting the targets to be achieved in a given area and their hierarchy. Each target was rated on a scale from -5 (intensity of negative influence) to 5 (intensity of positive influence), in categories such as: influence on natural heritage; cultural; fulfilling the needs of the society; effect on functional-spatial order; fulfilling the needs of the local community; costs of achieving goals; and influence on the values of landscape physiognomy.

The target that reached the most points has become a priority and the most important in the hierarchy. Subsequently, variants of the functional-spatial structure were introduced, it means a development of various variants that would enable to achieve a priority target was made. Each variant was evaluated in a similar way to the variant analysis.

After preparing the summary bonitation, a variant with the most points was chosen - it means was the most beneficial to achieve the priority target. The last stage of the SWOT analysis was variation of the landscape style. In order to determine the most coherent style of the examined area, each variant was rated on a scale from -5 to +5 points, in such categories as: effect on natural heritage; effect on cultural heritage; educational effect and implementation costs.

\section{RESULTS}

In the studied area we identified many different forms of land cover. The largest part of the analyzed area was covered by meliorated meadows (about 26\%), located in the central and north-eastern part. Another large part occupied orchards (about 21\%), unevenly distributed throughout the area (Fig. 2).

The valuable natural resources of the area included: the Bystrzyca River valley with the aquatic vegetation that crosses the entire study area, a small fragment of deciduous forests in the north-eastern part (about 2\%), wet meadows adjacent to the Hajdów sewage treatment (approximate 4\%), as well as a large number of trees, mainly in the western part (about 18\%) (Fig. 2). 
In the studied area there were also anthropogenic land cover forms, such as single farm buildings (1\%), group of farms (7\%), agricultural fields (about 11\%), road and railway infrastructure, shopping and service buildings and a large industrial - economic object (Fig. 2).

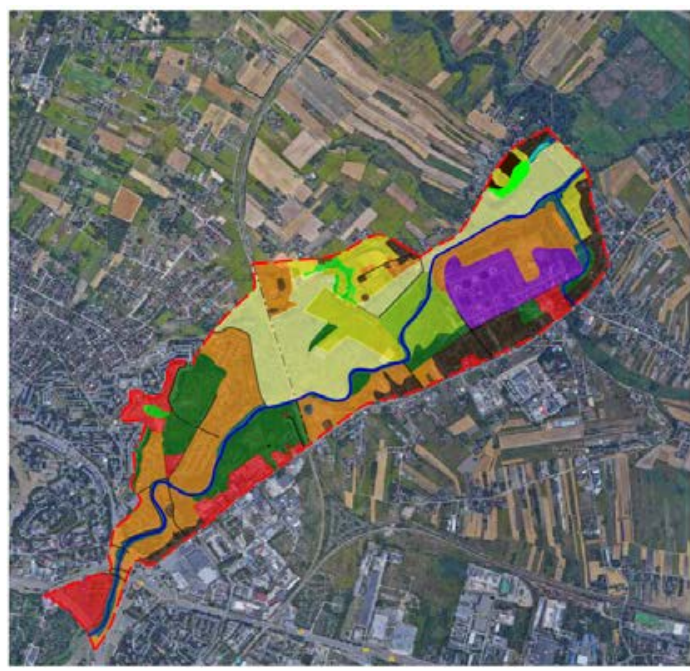

\section{Legend:}

-- Study area

National road

Road

Railway

Flowing water

Standing water

Deciduous forest

Trees

Aquatic vegetation

Wet meadow

Ameliorated meadow

Orchard

Agriculture field

Single farm building

Group of farm buildings

Shopping and service object

Industrial - economic object

Figure 2: Land cover forms in studied area.

The studied area was characterized by varied forms of terrain. Along the flowing waters of the Bystrzyca River, a vast areas of its valleys stretched, which made up over $70 \%$ of the area. In the south there were gentle slopes, cut in the central part by the highlands, whereas in the north, along boundary of the examined area - steep slopes. Among interesting morphological forms - ravines, irregularly arranged in the analyzed area, as well as isle bergs forms, occurring in the central part could be distinguished (Fig. 3).

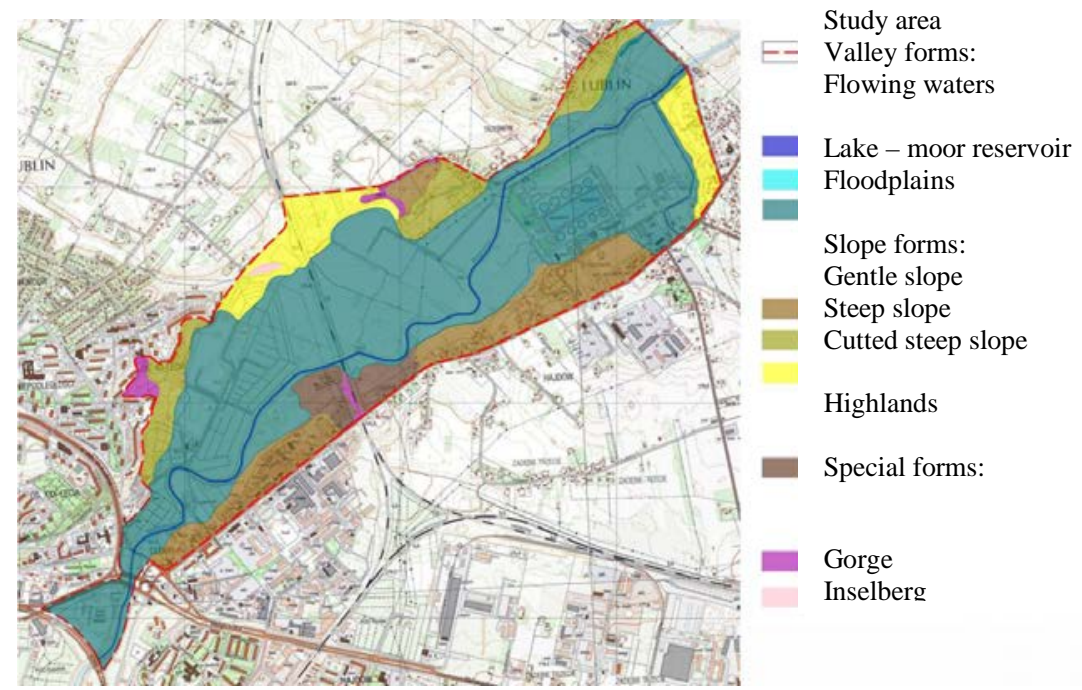

Figure 3: Terrain forms in studied area.

On the basis of the boundaries of land cover and terrain forms, 63 natural - landscape units were distinguished (JPK) (Fig. 4). 


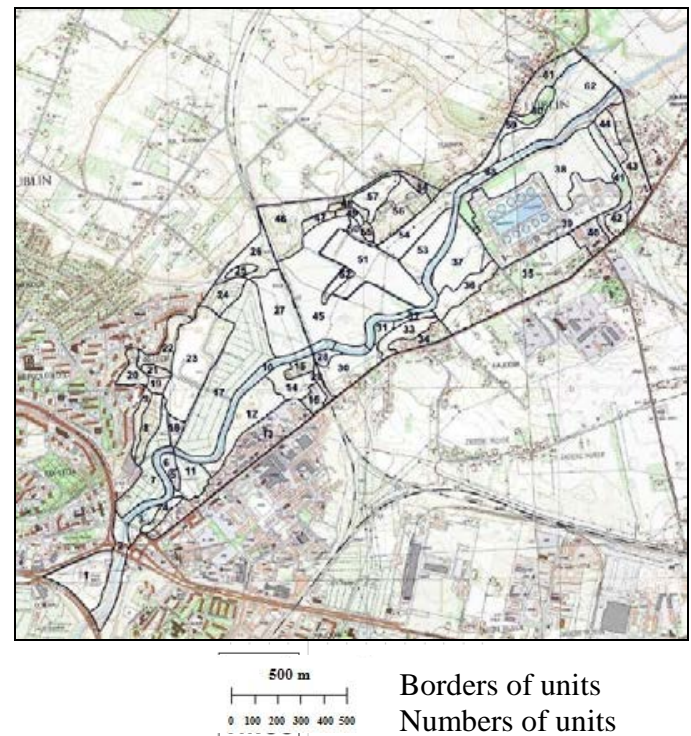

Figure 4: System of 63 natural - landscape units.

The questionnaire was completed by 67 persons. $84 \%$ are part of the second age group, $13.4 \%$ were $25-35$ years old. Smallest individuals group belong to the I, V and VI age classes - a total of $3 \%$. More than half of these people (65.7\%) had higher education, the others were characterized by secondary education.

On the question about forms of active tourism most often cultivated by respondents (choice of maximum two options), over half voted in favor of walking (50.9\%). Interest in cycling was also a popular choice for almost $36 \%$ of respondents. Canoeing proved to be the third most popular form of active tourism (8\%). The lowest number of surveyed chose horse riding and sailing and others, together 7\% (Fig. 5).

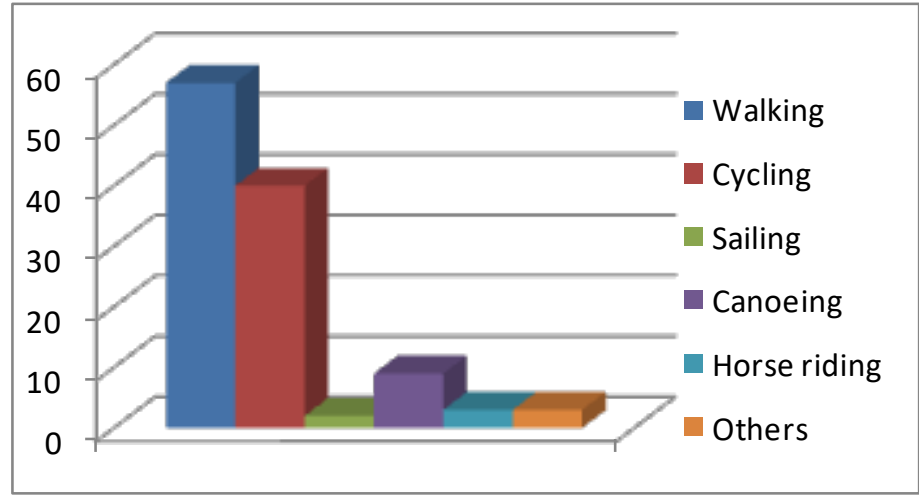

Figure 5: Most preferable forms of active tourism.

It turned out that $61.2 \%$ of respondents used walking and bicycle paths along the river, although the most people did it rarely (58.2\%), and only $14.9 \%$ - frequent. The rest of the respondents did not use these paths in general (26.9\%) (Fig. 6). 


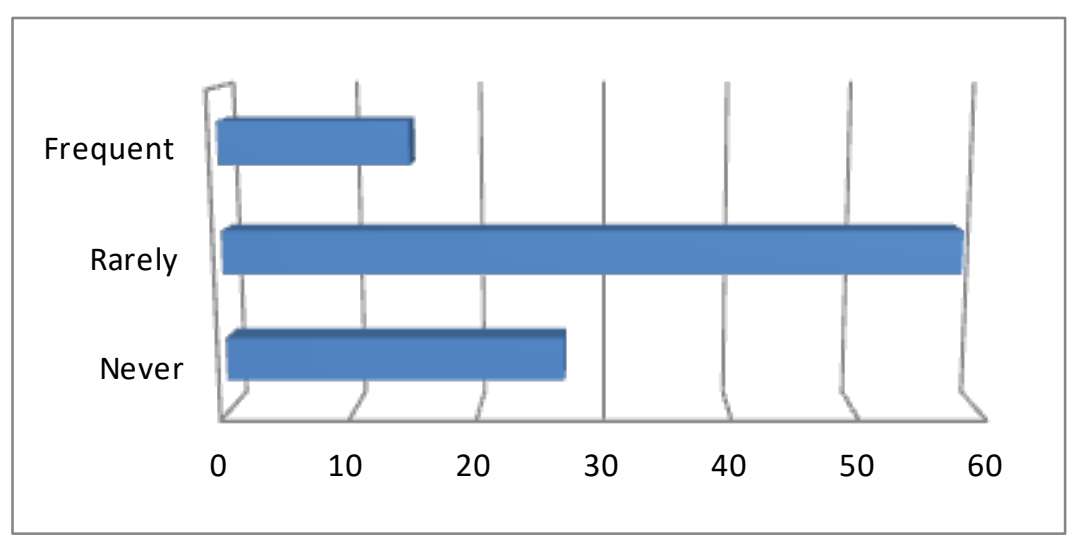

Figure 6: Frequency of paths’ using along the Bystrzyca River.

Most of the respondents (91\%) asked about the extension of the cycling-walking path in the south-eastern part of the city agreed to the idea, whereas only $9 \%$ were opposed.

More than half (52.2\%) rated attractiveness of tourist infrastructure in the Bystrzyca River valley as average by choosing on a scale number three, whereas $19.4 \%$ of respondents rated as four. The other (28.6\%) considered it to be below average. None of the respondents considered the current infrastructure on Bystrzyca River as very attractive (Fig. 7).

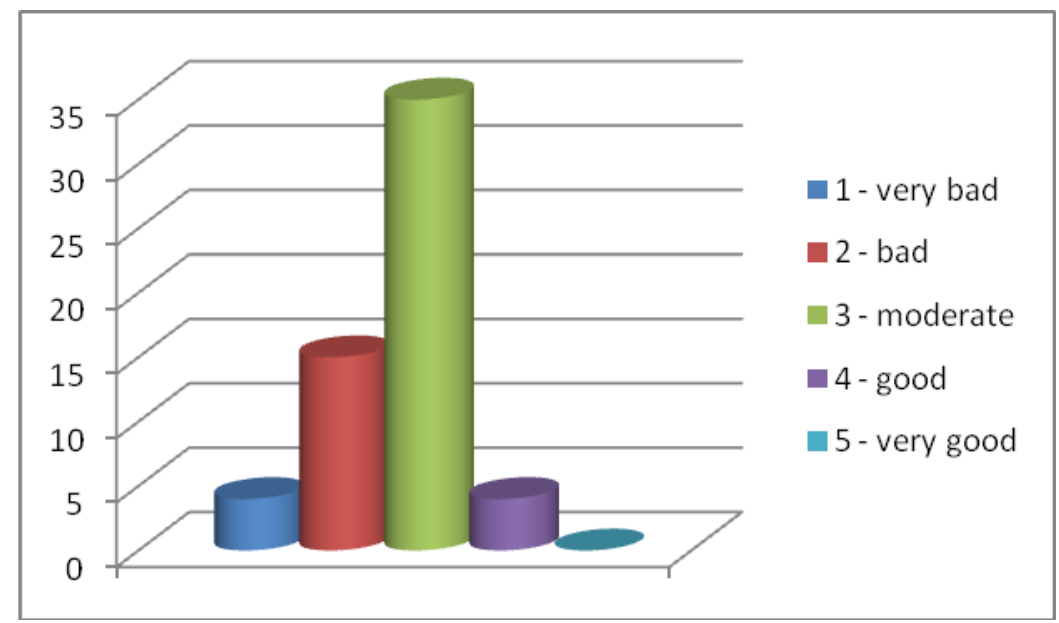

Figure 7: Evaluation of attractiveness of tourist infrastructure.

Thirty eight respondents voted for the purification of waters and adjacent areas from rubbish. 29 people voted for the introduction of lighting on walking and bicycle paths. The improvement of water quality in the river also proved to be important for respondents. 16 surveyed were in favor of the creation of a green squares near the river, and 13 respondents opted for an extension of the walking- cycling path in the south-east part of the city. Only four interviewed people voted for the creation of anglers’ platforms (Fig. 8). 


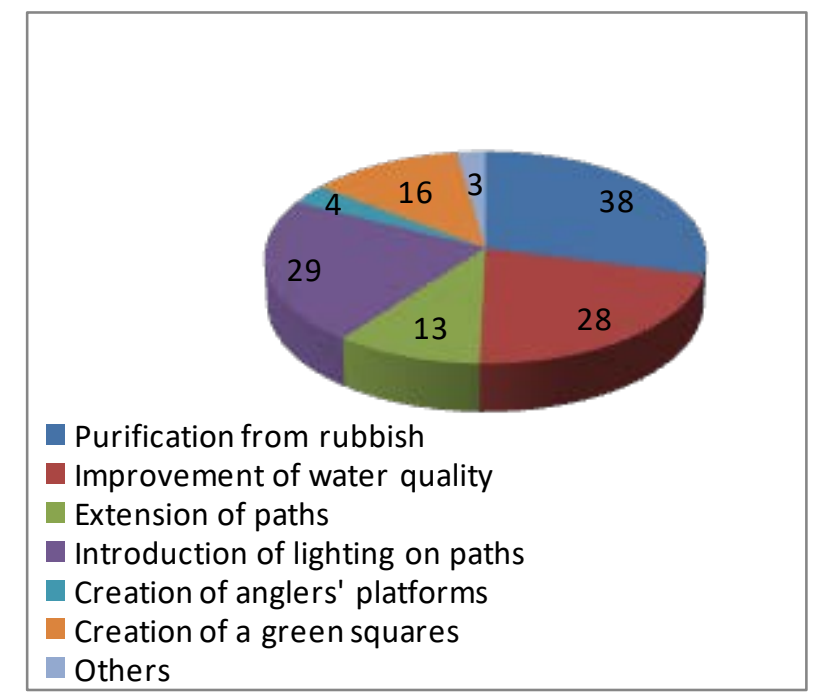

Figure 8: Activities improving recreational attractiveness of the Bystrzyca River valley.

The SWOT analysis showed that strengths of the area included the natural heritage and landscape physiology, as the river valley was a very valuable ecological corridor in such anthropogenically changed space. Terrain and land cover of the area was varied from the meadow ecosystems located in the river valley, through deciduous forests on the steep slopes to the gentle slopes. The weaknesses primarily included the lack of cultural heritage and the lack of tourist infrastructure, a chaotic spatial development, the economy, which is largely focused on the build over more and more valleys and the lack of protective areas to save the richness of natural environment in the studied area. The greatest opportunities for improvement and development were granted to the natural and cultural heritage, landscape physiology and spatial management of the area. The greatest threats included degradation of the natural heritage, decrease in the number of semi-natural areas in favor of anthropogenic areas, as well as economy oriented to buildings (Tab. 1).

Table 1: Diagnosis of local landscape’ status.

\begin{tabular}{|c|c|c|c|c|c|c|c|c|}
\hline \multirow[t]{2}{*}{ Domain } & \multicolumn{2}{|c|}{$\begin{array}{l}\text { Strengths } \\
\text { (S) }\end{array}$} & \multicolumn{2}{|c|}{$\begin{array}{l}\text { Weaknesses } \\
\text { (W) }\end{array}$} & \multicolumn{2}{|c|}{$\begin{array}{l}\text { Opportunities } \\
\text { (O) }\end{array}$} & \multicolumn{2}{|c|}{$\begin{array}{l}\text { Threats } \\
\text { (T) }\end{array}$} \\
\hline & Description & $\begin{array}{c}\text { Point } \\
0-5\end{array}$ & Descript. & $\begin{array}{l}\text { P. } \\
5-0\end{array}$ & Descript. & $\begin{array}{l}\mathrm{P} . \\
0-5\end{array}$ & Descript. & $\begin{array}{l}\text { P. } \\
5-0\end{array}$ \\
\hline $\begin{array}{l}\text { Natural } \\
\text { heritage }\end{array}$ & $\begin{array}{c}\text { A1) The } \\
\text { presence of } \\
\text { Bystrzyca } \\
\text { Valley with } \\
\text { rich aquatic } \\
\text { vegetation, } \\
\text { numerous } \\
\text { meliorated } \\
\text { and natural } \\
\text { meadows, } \\
\text { deciduous } \\
\text { forests. }\end{array}$ & 4 & $\begin{array}{c}\text { A2) Small } \\
\text { number of } \\
\text { natural } \\
\text { forms of } \\
\text { nature, } \\
\text { pollution. }\end{array}$ & -1 & $\begin{array}{c}\text { A3) The } \\
\text { Bystrzyca } \\
\text { River } \\
\text { valley as a } \\
\text { valuable } \\
\text { ecological } \\
\text { corridor, } \\
\text { ecological } \\
\text { manageme } \\
\text { nt of the } \\
\text { river } \\
\text { valley. }\end{array}$ & 5 & $\begin{array}{c}\text { A4) } \\
\text { Susceptibilit } \\
\text { y to adverse } \\
\text { effects, the } \\
\text { threat of } \\
\text { industrial } \\
\text { and } \\
\text { economic } \\
\text { facilities, } \\
\text { lack of } \\
\text { buffer } \\
\text { zones. }\end{array}$ & -3 \\
\hline
\end{tabular}


Table 1 (continued): Diagnosis of local landscape' status.

\begin{tabular}{|c|c|c|c|c|c|c|c|c|}
\hline \multirow[t]{2}{*}{ Domain } & \multicolumn{2}{|c|}{$\begin{array}{l}\text { Strengths } \\
\text { (S) }\end{array}$} & \multicolumn{2}{|c|}{$\begin{array}{l}\text { Weaknesses } \\
\text { (W) }\end{array}$} & \multicolumn{2}{|c|}{$\begin{array}{l}\text { Opportunities } \\
\text { (O) }\end{array}$} & \multicolumn{2}{|c|}{$\begin{array}{l}\text { Threats } \\
\text { (T) }\end{array}$} \\
\hline & Description & $\begin{array}{l}\text { Point } \\
0-5\end{array}$ & Descript. & $\begin{array}{c}\mathrm{P} . \\
5-0\end{array}$ & Descript. & $\begin{array}{l}\text { P. } \\
0-5\end{array}$ & Descript. & $\begin{array}{l}\text { P. } \\
5-0\end{array}$ \\
\hline $\begin{array}{l}\text { Cultural } \\
\text { heritage }\end{array}$ & $\begin{array}{l}\text { B1) There are } \\
\text { no cultural } \\
\text { facilities in } \\
\text { the study area } \\
\text { except } \\
\text { roadside } \\
\text { chapels. }\end{array}$ & 1 & $\begin{array}{l}\text { B2) Lack of } \\
\text { culturally } \\
\text { valuable } \\
\text { points. }\end{array}$ & -3 & $\begin{array}{c}\text { B3) } \\
\text { Possibility } \\
\text { of creating } \\
\text { cultural } \\
\text { centers, } \\
\text { enriching } \\
\text { the natural } \\
\text { heritage. }\end{array}$ & 4 & $\begin{array}{l}\text { B4) The } \\
\text { lack of } \\
\text { developmen } \\
\text { t of the area } \\
\text { in terms of } \\
\text { cultural } \\
\text { heritage. }\end{array}$ & -1 \\
\hline Society & $\begin{array}{l}\text { C1) The } \\
\text { presence of } \\
\text { garden } \\
\text { parcels and } \\
\text { bicycle paths } \\
\text { promotes the } \\
\text { integration of } \\
\text { society. }\end{array}$ & 3 & $\begin{array}{l}\text { C2) Blocks } \\
\text { mixed with } \\
\text { single and } \\
\text { compact } \\
\text { farmhouses, } \\
\text { small } \\
\text { degree of } \\
\text { integration. }\end{array}$ & -2 & $\begin{array}{c}\text { C3) } \\
\text { Develop- } \\
\text { ment of } \\
\text { enviro- } \\
\text { nmental } \\
\text { awareness, } \\
\text { tourism } \\
\text { and } \\
\text { spatial- } \\
\text { functional } \\
\text { order, } \\
\text { which } \\
\text { improve } \\
\text { the local } \\
\text { communit } \\
y\end{array}$ & 3 & $\begin{array}{c}\text { C4) } \\
\text { Division of } \\
\text { society, a } \\
\text { small } \\
\text { degree of } \\
\text { integration, } \\
\text { lack of } \\
\text { interest in } \\
\text { environmen } \\
\text { tal } \\
\text { problems. }\end{array}$ & -2 \\
\hline $\begin{array}{c}\text { Spatial } \\
\text { planning }\end{array}$ & $\begin{array}{c}\text { D1) } \\
\text { Expanded } \\
\text { road network, } \\
\text { accessibility } \\
\text { to services, } \\
\text { close } \\
\text { proximity to } \\
\text { nature. }\end{array}$ & 2 & $\begin{array}{c}\mathrm{D} 2) \\
\text { Functional- } \\
\text { spatial } \\
\text { disorder, } \\
\text { dispersed } \\
\text { single- } \\
\text { family } \\
\text { housing, } \\
\text { dominance } \\
\text { of buildings } \\
\text { over natural } \\
\text { environment } \\
\text { lack of river’ } \\
\text { and its } \\
\text { adjoining } \\
\text { areas } \\
\text { development }\end{array}$ & -3 & $\begin{array}{c}\text { D3) } \\
\text { Ecological } \\
\text { and tourist } \\
\text { developm } \\
\text { ent of the } \\
\text { Bystrzyca } \\
\text { River } \\
\text { valley }\end{array}$ & 4 & $\begin{array}{c}\text { D4) } \\
\text { Developme } \\
\text { nt of } \\
\text { dispersed } \\
\text { buildings } \\
\text { and road } \\
\text { infrastructur } \\
\text { e, lack of } \\
\text { buffer zones } \\
\text { protecting } \\
\text { the river } \\
\text { valley from } \\
\text { the } \\
\text { pollution. }\end{array}$ & -1 \\
\hline
\end{tabular}


Table 1 (continued): Diagnosis of local landscape' status.

\begin{tabular}{|c|c|c|c|c|c|c|c|c|}
\hline \multirow[t]{2}{*}{ Domain } & \multicolumn{2}{|c|}{$\begin{array}{l}\text { Strengths } \\
\text { (S) }\end{array}$} & \multicolumn{2}{|c|}{$\begin{array}{l}\text { Weaknesses } \\
\text { (W) }\end{array}$} & \multicolumn{2}{|c|}{$\begin{array}{l}\text { Opportunities } \\
\text { (O) }\end{array}$} & \multicolumn{2}{|c|}{$\begin{array}{l}\text { Threats } \\
\text { (T) }\end{array}$} \\
\hline & Description & $\begin{array}{c}\text { Point } \\
0-5\end{array}$ & Descript. & $\begin{array}{c}\text { P. } \\
\text { 5-0 }\end{array}$ & Descript. & $\begin{array}{c}\text { P. } \\
0-5\end{array}$ & Descript. & $\begin{array}{c}P . \\
5-0\end{array}$ \\
\hline $\begin{array}{l}\text { Eco- } \\
\text { nomy }\end{array}$ & $\begin{array}{l}\text { E1) Expanded } \\
\text { agricultural } \\
\text { and industrial } \\
\text { service. }\end{array}$ & 2 & $\begin{array}{c}\text { E2) A } \\
\text { negative } \\
\text { impact of } \\
\text { the } \\
\text { developed } \\
\text { economy on } \\
\text { the } \\
\text { ecological } \\
\text { status of the } \\
\text { area } \\
\text { (surface } \\
\text { runoff from } \\
\text { fields, } \\
\text { littering, } \\
\text { odors in the } \\
\text { vicinity of } \\
\text { sewage } \\
\text { treatment } \\
\text { plants, } \\
\text { polluted } \\
\text { river } \\
\text { waters). }\end{array}$ & -3 & $\begin{array}{l}\text { E3) } \\
\text { Intensifica } \\
\text { tion of } \\
\text { ecological } \\
\text { and } \\
\text { tourism } \\
\text { economy } \\
\text { of the } \\
\text { examined } \\
\text { area, } \\
\text { taking into } \\
\text { account } \\
\text { needs of } \\
\text { the local } \\
\text { community }\end{array}$ & 3 & $\begin{array}{c}\text { E4) } \\
\text { Environmen } \\
\text { tal } \\
\text { degradation, } \\
\text { the lack of } \\
\text { taking into } \\
\text { account of } \\
\text { environmen } \\
\text { tal } \\
\text { protection } \\
\text { in the area } \\
\text { in economic } \\
\text { development }\end{array}$ & -1 \\
\hline $\begin{array}{l}\text { Land- } \\
\text { scape } \\
\text { physio- } \\
\text { logy }\end{array}$ & $\begin{array}{l}\text { F1) The } \\
\text { occurrence of } \\
\text { interesting } \\
\text { forms of } \\
\text { terrain - river } \\
\text { valley, isle } \\
\text { bergs, plateau } \\
\text { gorge, and } \\
\text { land cover - } \\
\text { flowing and } \\
\text { standing } \\
\text { waters, } \\
\text { deciduous } \\
\text { forests, } \\
\text { grasslands. }\end{array}$ & 4 & $\begin{array}{l}\text { F2) The } \\
\text { lack of } \\
\text { visibility of } \\
\text { positive } \\
\text { characteri- } \\
\text { stics of } \\
\text { natural } \\
\text { landscape, } \\
\text { overwhelm- } \\
\text { ed by } \\
\text { anthropogen } \\
\text { ic elements, } \\
\text { the lack of } \\
\text { positive } \\
\text { aesthetic } \\
\text { qualities. }\end{array}$ & -2 & $\begin{array}{c}\text { F3) } \\
\text { Creation } \\
\text { of } \\
\text { protected } \\
\text { areas to } \\
\text { preserve } \\
\text { and } \\
\text { enhance } \\
\text { the } \\
\text { richness of } \\
\text { animated } \\
\text { and } \\
\text { inanimate } \\
\text { nature, } \\
\text { afforestati } \\
\text { on, tree } \\
\text { planting, } \\
\text { more } \\
\text { attention } \\
\text { to nature. }\end{array}$ & 5 & $\begin{array}{c}\text { F4) } \\
\text { Extrusion of } \\
\text { positive } \\
\text { elements of } \\
\text { nature with } \\
\text { anthropogen } \\
\text { ic elements } \\
\text { - bridges, } \\
\text { fast-moving } \\
\text { roads, } \\
\text { buildings, } \\
\text { which can } \\
\text { cause even } \\
\text { more } \\
\text { degradation } \\
\text { of the } \\
\text { environmen } \\
\text { t. }\end{array}$ & -4 \\
\hline
\end{tabular}


Table 1 (continued): Diagnosis of local landscape' status.

\begin{tabular}{|c|c|c|c|c|c|c|c|c|}
\hline Domain & \multicolumn{2}{|c|}{$\begin{array}{c}\text { Strengths } \\
\text { (S) }\end{array}$} & \multicolumn{2}{c|}{$\begin{array}{c}\text { Weaknesses } \\
\text { (W) }\end{array}$} & $\begin{array}{c}\text { Opportunities } \\
\text { (O) }\end{array}$ & \multicolumn{2}{c|}{$\begin{array}{c}\text { Threats } \\
\text { (T) }\end{array}$} \\
\hline & Description & $\begin{array}{c}\text { Point } \\
0-5\end{array}$ & Descript. & $\begin{array}{c}\text { P. } \\
\text { D-0 }\end{array}$ & Descript. & $\begin{array}{c}\text { P. } \\
0-5\end{array}$ & Descript. & P. \\
\hline $\begin{array}{c}\text { Summa- } \\
\text { ry } \\
\text { bonita- } \\
\text { tion }\end{array}$ & 16 & & -15 & & 22 & & -12 & \\
\hline
\end{tabular}

Based on the results of the landscape status' diagnosis, objectives that were desirable and achievable in the area have been identified (Tab. 2).

Table 2: Evaluation of targets implementation, choice and prioritizing.

\begin{tabular}{|c|c|c|c|}
\hline $\begin{array}{c}\text { Evaluation of } \\
\text { implementation' effects of } \\
\text { the concept of land } \\
\text { planning development } \\
\text { Preservation of semi- } \\
\text { natural character of } \\
\text { landscape and increase } \\
\text { of ecological potential } \\
\text { of the Bystrzyca } \\
\text { Valley }\end{array}$ & $\begin{array}{c}\text { Target II: } \\
\text { Development of } \\
\text { cultural heritage }\end{array}$ & $\begin{array}{c}\text { Target III: } \\
\text { Increasing of } \\
\text { recreational and } \\
\text { sporting } \\
\text { attractiveness }\end{array}$ \\
\hline $\begin{array}{c}\text { Influence on natural } \\
\text { heritage }\end{array}$ & 5 & 1 & -1 \\
\hline $\begin{array}{c}\text { Influence on cultural } \\
\text { heritage }\end{array}$ & 3 & 5 & 0 \\
\hline Society needs fulfilling & 4 & 4 & 3 \\
\hline $\begin{array}{c}\text { Effect on functional- } \\
\text { spatial order }\end{array}$ & 3 & 2 & 5 \\
\hline $\begin{array}{c}\text { Fulfilling the needs of the } \\
\text { local community }\end{array}$ & 4 & -3 & -5 \\
\hline Costs of achieving a target & -3 & 2 & 1 \\
\hline $\begin{array}{c}\text { Influence on the values of } \\
\text { landscape physiognomy }\end{array}$ & 5 & 14 & 11 \\
\hline Summary bonitation & 21 & Recommended \\
\hline realization & $\begin{array}{c}\text { Recommended } \\
\text { realization }\end{array}$ \\
\hline
\end{tabular}

As a priority, "target I" was chosen to preserve the semi-natural character of the landscape and increase an ecological potential of the Bystrzyca Valley, given its important ecological role in the area and great chances for development and improvement of the present status. The "target II" - the development of cultural heritage in the studied area was included in the recommendations for the less favorable impact on the assessed aspects of the implementation effects of the land use concept. Likewise, "target III" - an increasing recreation and sport attractiveness, which could additionally have negative consequences in the form of degradation and pollution of the natural environment and high cost of implementation. 
Concepts of three variants implementing objectives combined activities aimed at achieving "target I" and elements of actions related to the implementation of "target III" in accordance with principles of sustainable development.

The "target I" assumed creation of a park and plantation of dry-ground forest in the south-west part of the area, the extension of the bike path along the river, and the formation of a viewpoint (Fig. 9).

The concept also presented opportunities for improving ecological conditions of the area by introducing filtering vegetation in the first and final sections of the river, creating oxygenation thresholds and subsoil to improve water quality in the river. It is also suggested to reconstruct aquatic vegetation and to create floodplains in valuable wetlands, as well as to create a protection zone to prevent further degradation and to create habitat conditions close to natural (Fig. 9).

Another important element of the concept is introduction of small water bodies, midfield trees and bushes, which would greatly contribute to accumulation of biogenic substances and reduce their surface runoff into the watercourse and to improve water retention in the study area.

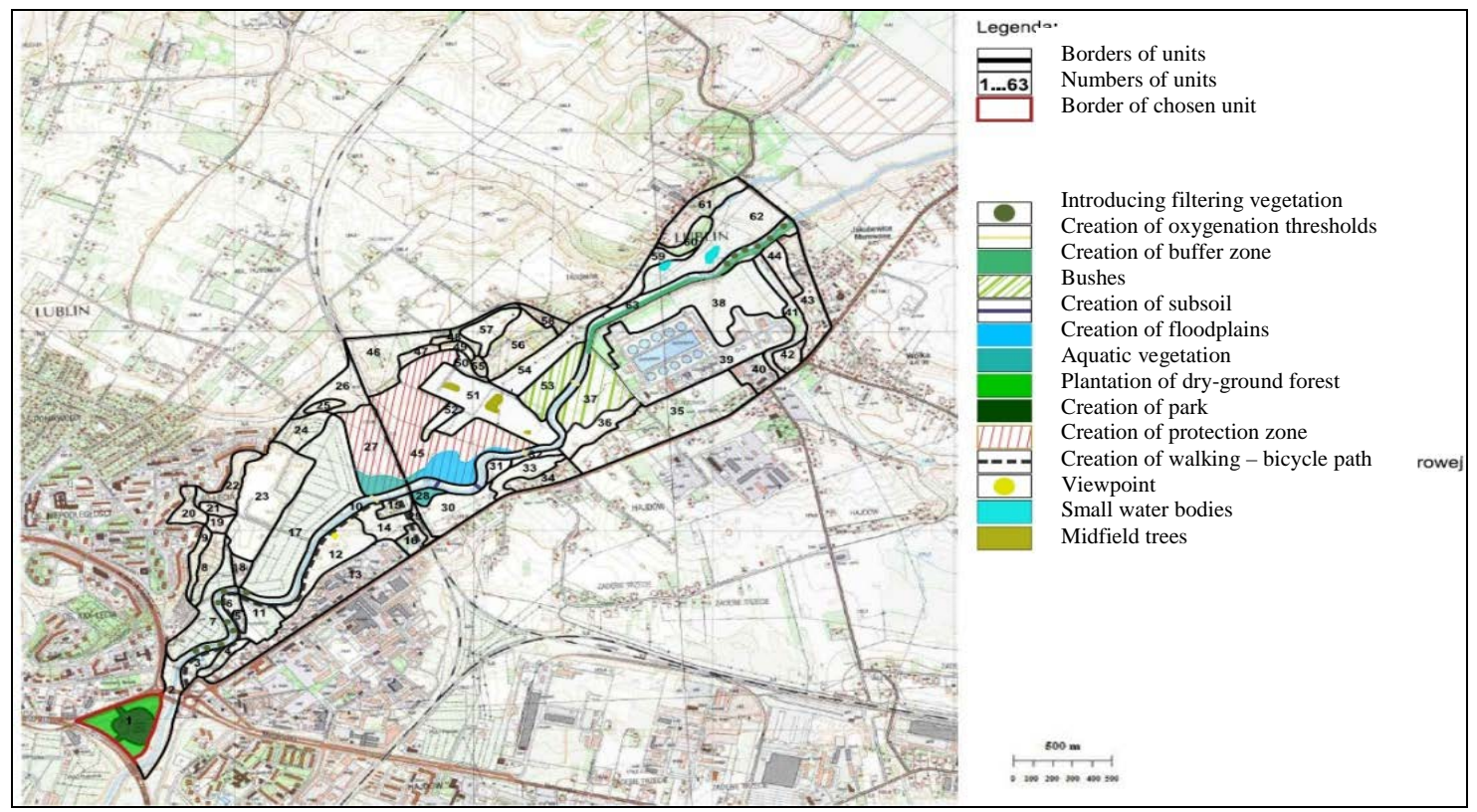

Figure 9: The "I variant" of functional-spatial structure.

As the best, "I variant" was considered because it influenced the most preferably on the evaluation of the effects of the concept and land development, mainly on the natural heritage, conditions of the area management, a landscape physiognomy and socio-economic effects (Tab. 3). 
Table 3: Variants' impact on evaluated aspect of concepts' realization and land planning development.

\begin{tabular}{|c|c|c|c|}
\hline Evaluated aspect & I variant & II variant & III variant \\
\hline Impact on natural values & 5 & 4 & 3 \\
\hline Impact on cultural values & 1 & 2 & 1 \\
\hline Impact on functional-spatial order & 3 & 2 & 1 \\
\hline Impact on site management conditions & 4 & 4 & 4 \\
\hline Implementation costs & -2 & -3 & -3 \\
\hline Expected socio-economic effects & 4 & 3 & 4 \\
\hline Impact on landscape physiognomy' values & 5 & 5 & 5 \\
\hline Summary bonitation & 20 & 17 & 15 \\
\hline Decision & $\begin{array}{c}\text { Priority } \\
\text { realization }\end{array}$ & $\begin{array}{l}\text { Recommended } \\
\text { realization }\end{array}$ & $\begin{array}{l}\text { Recommended } \\
\text { realization }\end{array}$ \\
\hline
\end{tabular}

\section{DISCUSSION}

The motivation for the study was information about the local community' needs in relation to the river valley located in the urbanized space and the essence and obligation of river valleys' revitalization in accordance with the Act of the Minister of the Environment from 2016.

River valleys are at the earliest used and transformed ecosystems. At present, revitalization - the main direction of development of cities in Poland, is seen as an opportunity for a new quality of a riverside urban space and improvement of functioning of river valleys in cities. These actions will contribute to improve living conditions and increase a tourism potential of cities (Bernat, 2013).

The Bystrzyca River and its valley in Lublin are characterized by great potential for recreation, nature and landscape. Unfortunately, yet it is not used enough. The Bystrzyca Valley, as an ecological corridor, connects 12 ecological links of the ecological structure (forests, meadows, garden plots) with urbanized centre (Bernat, 2013). Water of the Bystrzyca River is characterized by IV class of water quality. The quality of inflow waters oscillated between III and IV class; in the city only Czechówka watercourse entered V class water (WIOŚ Lublin, 2005).

River Valleys are considered to be extremely important areas, particularly in areas characterized by a high degree of anthropogenic transformation. In many cities a river valley contributes to one of the few open spaces with free air exchange and a specific microclimate (Bernat, 2013). In the settlement space river valleys are also elements of a social bond and concentration of inhabitants fulfilling their needs here: volatility and stability, silence and bustle, calm and movement, loneliness and community participation, anonymity and public appearances or individual expression of their personality (Wallis, 1971). Therefore, it is very important to familiarize with opinion and needs of the society and their direct participation in decision-making process. Inhabitants' participation in environmental issues has a lot of positive aspects, e.g. promoting a connection between people and nature (Devictor et al., 2010; Hobbs and White, 2012) or raising awareness of environment (Brossard et al., 2005; Jones-Walters and Cil, 2011), what was underlined by many authors so far (Buchecker et al., 2003). 
One of the methods of participation of local community in public areas' changes is to conduct a survey. It allows to anonymously expressing own feelings, desires, expectations or ideas. A questionnaire about the Bystrzyca Valley conducted in Lublin allowed to create a hierarchy of actions to be taken in this area. The priority for most respondents was not a creation of additional attractions and diversifies the site, but cleaning up and improvement of water quality. This not only proves the environmental consciousness of society, but also a fatal status of the environment that is noticeable even to the inexperienced observer. A large number of respondents also pointed to the need to light walking and bicycle paths, which indicates lack of security and draws attention to limiting use during rest of the year. A fact of local society' participation in the development of the area, is also supported by city authorities. An example may be Piotrków Trybunalski city, where among inhabitants a survey was conducted, based on which the revitalization project was chosen. It was mainly based on the renewal of the old Town, which in opinion of the most inhabitants had the greatest potential and chances to become a city symbol. The significance of society' participation was emphasized by Czyżewska (2010).

The basis for action was division into spatial units, relatively closed, composed from interconnected geocomponents or lower level systems, to carry out an analyze of the landscape structure (Richling, 1997). This process importance has been emphasized by Chmielewski (2013), because natural - landscape units (JPK) comprehensively map the structure of many individual components of the environment, providing reference systems for landscape research. Various scientific disciplines dealing with the landscape have worked out and applied different land division systems into basic natural spatial units. Among them are two basic, first supported by proponents of the concept of environmental continuity - the division into units of natural boundaries, whereas the second one - the division into artificial, geometric basic fields, applied uniformly and randomly to a map or political, administrative divisions, conducted due to economic premise or location of the population (Chmielewski, 2012).

During assigning units based on natural boundaries, a various criteria depending on the type of landscape and the purpose of an analysis are accepted. By studying the fragment of the Bystrzyca Valley, a method of division into natural-landscape units based on boundaries of terrain and land cover form was applied. On this basis, the following types of landscape were distinguished: deciduous forests on gentle slopes, grassland meadows in river valley, compact farmland on steep slopes or greenery production on steep slopes. Designated units provided the basis for assessing the ecological potential of the area, its aesthetic value, and the potential for improvement and development of the area by introducing new facilities and functions. Natural - landscape units were a base of Wyrzykowski (2000), who apart from land cover and terrain, took into account the degree of anthropogenic transformation. Balon and Krąż (2013) considered that criteria for separating units should differentiating a landscape: e.g. geological criteria (lithology and tectonics), or geomorphological criteria (terrain types).

In the study natural boundaries of basins, patches, forests, rivers and buildings, without interrupting continuity in the landscape, were used to create natural - landscape units (JPK). As a result, an appropriate degree of homogeneity of the allocated landscape units has been achieved to facilitate further research and analysis. In similar analyzes various criteria of division were used, which means that the basic field can be extracted from any set of elements that simultaneously show directed and significant links from the perspective of the study area and occurring processes (Richling, 1997). 
Revitalization is a complex, often long-term process, which aims at giving a new quality to a degraded area. Revitalization is seen as an opportunity to improve the quality of urban riverside spaces, which should be natural and valuable public spaces (Domańska, 2012). The analyzed part of the Bystrzyca Valley is located in strongly transformed anthropogenic space, what makes it particularly sensitive to pollution and unfavorable transformations. Taking into account the great importance of such ecosystems in nature and many other important social functions, their proper management is high important. Presented in the work concept of development of the Bystrzyca Valley was based on sequential activities, including: land reconnaissance, study of terrain' determinants, natural inventory, identification of user needs, establishment of conceptual guidelines and hierarchy of objectives and ways of achieving them and a choice of the most favorable concept for nature and society.

Developed in that way concept primarily assumed improvement of the environment status and the quality of water in this area. Activities aimed at revitalization included: introduction of filtering vegetation, restoration of aquatic vegetation, creation of protected zone on adjacent areas, creation of floodplains, oxygenation thresholds, subterranean, small water bodies and midfield trees and bushes.

\section{CONCLUSIONS}

The analyzed part of the Bystrzyca River valley within the Lublin city provides a refuge of valuable natural habitats, which are overwhelmed by anthropogenic forms of land cover.

The strengths of the area include large ecological potential and a variety of forms of land cover and terrain, whereas weaknesses - the lack of development of tourism and cultural heritage, a chaotic spatial development, as well as development of buildings.

According to the respondents, the Bystrzyca Valley is not attractive to tourists, and its main reason is poor status of the natural environment.

The conservation of the semi-natural character of the landscape and the enhancement of the ecological potential of the Bystrzyca Valley has been recognized as priority activities in the studied area.

As the best variant fulfill a priority purpose, variant no. I was chosen. It concerns creation of floodplains, protection zone, improvement of water quality and creation of a walking - bicycle path.

\section{ACKNOWLEDGEMENTS}

Firstly, the authors would like to thank to Mrs. Curtean-Bănăduc A. and Mr. Bănăduc D., the editors of Transylvanian Review of Systematical and Ecological Research for their continuous support. Secondly, we would like to thank to students Marucha P. and Kuk M. for their great contribution in creation of this work. 


\section{REFERENCES}

1. Balon J. and Krąż P., 2013 - Ocena jakości krajobrazu: dobór prawidłowych jednostek krajobrazowych/Landscape quality assessment: selection of correct landscape units, in Identyfikacja i waloryzacja krajobrazów - wdrażanie Europejskiej Konwencji Krajobrazowej, Generalna Dyrekcja Ochrony Środowiska, Warszawa, 58-63. (in Polish)

2. Benton T. G., Vickery J. A. and Wilson J. D., 2003 - Farmland biodiversity: is habitat heterogeneity the key? Trends in Ecology and Evolution, 18, 182-188.

3. Bernat S., 2010 - Doliny rzeczne i ich percepcja, Krajobrazy kulturowe dolin rzecznych, potencjał i wykorzystanie/River valleys and their perception, Cultural landscapes of river valleys, potential and use, Prace Komisji Krajobrazu Kulturowego PTG, Sosnowiec, 13, 167178. (in Polish)

4. Bernat S., 2013 - Atrakcyjność turystyczno-rekreacyjna dolin rzecznych a ich rewitalizacja na przykładzie doliny Bystrzycy w Lublinie/Tourism and recreation attractiveness of river valleys and their revitalization on the example of Bystrzyca Valley in Lublin, Problemy Rozwoju Miast, 10, 2, 41-52. (in Polish)

5. Brossard D., Lewenstein B. and Bonney R., 2005 - Scientific knowledge and attitude change: The impact of a citizen science project, International Journal of Science Education, 27, 10991121.

6. Buchecker M., Hunziker M. and Kienast F., 2003 - Participatory landscape development: overcoming social barriers to public involvement, Landscape and Urban Planning, 64, 29-46.

7. Bullock A. and Acreman M., 2003 - The role of wetlands in the hydrological cycle, Hydrology and Earth System Sciences Discussions, 7, 3, 358-389.

8. Chmielewski T. J., 2013 - Standardy i wskaźniki jakości krajobrazu, Identyfikacja i waloryzacja krajobrazów - wdrażanie Europejskiej Konwencji Krajobrazowej/Standards and indicators of landscape quality, Identification and valorisation of landscapes - implementation of the European Landscape Convention, GDOŚ, Warszawa, 43-57. (in Polish)

9. Chmielewski T. J., 2012 - Systemy krajobrazowe: struktura, funkcjonowanie, planowanie/Landscape systems: structure, functioning, planning, Wydawnictwo Naukowe PWN, Warszawa, 408. (in Polish)

10. Crooks K. R., Suarez A. V. and Bolger D. T., 2004 - Avian assemblages along a gradient of urbanization in a highly fragmented landscape, Biological Conservation, 115, 451-462.

11. Czyżewska A., 2010 - Jak planować proces rewitalizacji społeczno-gospodarczej przestrzeni miejskiej?/How to plan the process of revitalization of socio-economic urban space? Pracowania Badań i Innowacji Społecznych, Stocznia, 1-18. (in Polish)

12. Devictor V., Whittaker R. J. and Beltrame C., 2010 - Beyond scarcity: Citizen science programmes as useful tools for conservation biogeography, Diversity and Distribution, 16, 354362.

13. Diamond J. M., Terborgh J., Whitcomb R. F., Lynch J. F. and Opler P. A., 1976 - Island biogeography and conservation: Strategy and limitations, Science, 193, 1027-1032.

14. Domańska J., 2012 - Przyszłość dolin rzecznych w miastach/Future of river valleys in cities, Czasopismo Techniczne, Architektura, 1, 1, 131-139. (in Polish)

15. Erwin K. L., 2009 - Wetlands and global climate change: the role of wetland restoration in a changing world, Wetlands Ecology and Management, 17, 1, 71-84.

16. Izydorczyk K., Frątczak W., Drobniewska A., Badowska M. and Zalewski M., 2010 Zastosowanie stref ekotonowych w ograniczaniu zanieczyszczeń obszarowych/Application of ecotone zones to reduce area pollution, Przeglad Komunalny, 10, 79-81. (in Polish)

17. Fahrig L., 2003 - Effects of habitat fragmentation on biodiversity, Annual Review of Ecology Evolution and Systematics, 34, 487-515.

18. Hobbs S. J., Piran C. L. and White P. C. L., 2012 - Motivations and barriers in relation to community participation in biodiversity recording, Journal for Nature Conservation, 20, 364373. 
19. Kerr J. T. and Deguise I., 2004 - Habitat loss and the limits to endangered species recovery, Ecology Letters, 7, 1163-1169.

20. Kijowski A. and Rączkowski W., 2007 - Przekształcenia w sieci osadniczej dolin rzecznych w Wielkopolsce i ich rola w planowaniu przestrzennym/Transformations in the settlement network of river valleys in Wielkopolska and their role in spatial planning, Doliny rzeczne, przyrodakrajobraz-człowiek, PTG, Sosnowiec, 7, 301-311. (in Polish)

21. Jones-Walters L. and Cil A., 2011 - Biodiversity and stakeholder participation, Journal for Nature Conservation, 19, 327-329.

22. Lipka K. and Stabryła J., 2012 - Wielofunkcyjność mokradeł w Polsce i świecie/Multifunctionality of wetlands in Poland and around the world, Współczesne Problemy Kształtowania i Ochrony, Monografie 3, 7-16. (in Polish)

23. Luck G. W., Ricketts T. H., Daily G. C. and Imhoff M., 2004 - Alleviating spatial conflict between people and biodiversity, Proceedings of the National Academy of Sciences of the United States of America, 101, 182-186.

24. MacArthur R. H. and Wilson E. O., 1967 - The theory of island biogeography - Monographs in populations biology, 1, Princeton University Press, Princeton, New Jersey, 203.

25. Matuszkiewicz J., Solon J., Roo-Zielińska E., Kowalska A. and Romanowski J., $2007-$ Zastosowanie scenariuszy ekologicznych dla poprawy partycypacji społecznej w planowaniu przestrzennym/Application of ecological scenarios to improve social participation in spatial planning, Urbanista 5, 53, 18-24. (in Polish)

26. Matuszkiewicz J. M., 1999 - Prognozy i waloryzacje przyrodnicze skutków różnych wariantów zagospodarowania hydrotechnicznego Wisły/Forecasts and valorisation of natural effects of different variants of the Vistula River' hydrotechnical development, (w:) M. Kucharczyk (ed.) in Problemy ochrony i renaturalizacji dolin dużych rzek Europy. Materiały Międzynarodowej Konferencji z okazji 20-lecia Kazimierskiego Parku Krajobrazowego, Lublin: Wydaw. UMCS, 165-172. (in Polish)

27. Plit J., 2008 - Zarzadzanie krajobrazem dolin rzecznych/Management of the landscape of river valleys, Zarządzanie krajobrazem kulturowym, przyroda-krajobraz-człowiek, PTG, Sosnowiec, 10, 230-240. (in Polish)

28. Richling A., 1997 - Problemy Ekologii Krajobrazu/Problems of Landscape Ecology, Wydawnictwo Paek, Kraków. (in Polish)

29. Sala O. E., Chapin F. S., Armesto J. J., Berlow E., Bloomfield J., Dirzo R., Huber-Sanwald E., Huenneke L. F., Jackson R. B., Kinzig A., Leemans R., Lodge D. M., Mooney H. A., Oesterheld M., Poff N. L., Sykes M. T., Walker B. H., Walker M. and Wall D. H., 2000 - Global biodiversity scenarios for the year 2100, Science, 287, 1770-1774.

30. Wyrzykowski J., 2000 - Conditions of the foreign tourism in the Central and Eastern Europe, in Wyrzykowski J. (ed.) Changes in model of tourism in the last decade, Wrocław, Zakład Geografii Regionalnej i Turystyki, 93-112.

31. Wallis A., 1971 - Socjologia i kształtowanie przestrzeni/Sociology and space shaping, PIW Warszawa, 1-228. (in Polish)

32. Water Framework Directive 2000/60/EC, 2000.

33. Wilcove D. S., Rothstein D., Dubow J., Phillips A. and Losos E., 1998 - Quantifying threats to imperiled species in the United States, Bioscience, 48, 607-615.

34. Żelazo J., 2006 - Renaturalizacja rzek i dolin/Renaturalization of rivers and valleys, Infrastruktura i ekologia terenów wiejskich, 4, 1, 11-31. (in Polish) 